\title{
Histopathologic Observation of the Aborted Fetus from Pregnant Dairy Cows Naturally Infected with Neospora caninum
}

\author{
Jeong-Hoon Son and Sung-Whan Cho* \\ College of Veterinary Medicine, Chungnam National University, Daejeon 305-764, Korea \\ Received September 2, 2010 / Accepted October 23, 2010
}

\begin{abstract}
This study examined the histopathologic and electron microscopic findings of aborted fetuses from pregnant dairy cows naturally infected with Neospora caninum (N. caninum) at four farms in Gongju city and Yeonki gun of Choongnam province. Systemic subcutaneous edema was observed in the aborted fetuses. The necropsy revealed considerable serosanguinous fluid in the body cavity of the aborted fetuses. Light microscopy showed the infiltration of many inflammatory cells consisting of macrophages, lymphocytes and mononuclear cells, accompanied by congestion, hemorrhage and necrosis of myocardiac cells and hepatocytes in the liver and heart of the aborted fetuses. In the liver, clusters of tachyzoites were formed in the cytoplasm of hepatocytes and the interstitial tissue. In the brain, many tissue cysts of various sizes were observed in the nerve cells and their adjacent areas. Tissue cysts had a round shape and contained a large amount of bradyzoite. In addition, there was diffuse gliosis accompanied by congestion and hemorrhage and focal necrosis in the brain. Infiltration of microglial cells were observed at the periphery of the focal necrosis and perivascular area in the brain. Electron microscopy showed that the tissue cyst wall had a thickness of approximately $1 \mu \mathrm{m}$ with an irregular shape. On the interior side, more than 100 bradyzoites with lengths of 2-5 $\mu \mathrm{m}$ and widths of 1-2 $\mu \mathrm{m}$ were observed. The nucleus of in the bradyzoites was located approximately 1-1.5 $\mu \mathrm{m}$ anterior to the posterior tip of the zoite. In the cytoplasm between the nucleus and the posterior tip, there were many amylopectin granules, electron-dense small-sized and electron-thin large-sized round granules, homogeneously electron-dense rhoptries and micronemes oriented perpendicularly to the zoite pellicle. To summarize, tissue cysts were identified on electron microscopy from the aborted fetus from N. caninum seropositive pregnant cow by the ELISA. This led to the confirmed presence of $N$. caninum.
\end{abstract}

Key words : Neospora caninum, bradyzoite, tissue cyst, ultrastructure, dairy cow

\section{서 론}

Neospora caninum (N. caninum)은 개에서 심각한 신경증상 을 일으키고 소에서는 주로 유산을 일으키는 원충으로 1984년 Bjerkås 등[5]에 의해 개에서 cyst forming sporozoon으로 처 음 발견되었으며, 이후 뇌척수염과 척수염을 보인 송아지에서 보고되었다[17,18]. Conrad 등[9]은 소의 유산된 태아에서 최 초로 기생충을 분리하였으며, Barr 등[3]은 이 기생충을 임신 우에 실험적으로 감염시켜 태아의 폐사와 선천적으로 감염된 송아지가 분만되는 것을 보고하였다.

소에서 Neospora로 인한 유산 발생은 1989년 Thilsted와 Dubey [22]가 미국 뉴멕시코주의 젖소 목장에서 처음으로 보 고한 이래, 전 세계적으로 발생하고 있다[2,10-13]. 소의 유산된 태아에서 Neospora 감염률은 캘리포니아, 네델란드와 뉴질랜 드에서 약 $20 \%$ 였으며, 지방병성(endemic) 유산과 유행병성 (epidemic) 유산이 발생했었던 목장의 유산 태아에서 Neospora

*Corresponding author

Tel : +82-42-821-6755, Fax : +82-42-821-8903

E-mail : swcho@cnu.ac.kr
감염율은 각각 $44 \%$ 와 $77 \%$ 에 달할 정도로 소의 유산에서 가장 중요한 원인으로 인식되고 있다[1,2,23].

목장에서 유산 발생시 Neospora 감염에 의한 유산인지를 확 인하는 방법으로 유산한 어미소와 유산된 태아의 혈청학적 진단법이 널리 이용되고 있으나 유산된 태아에서 Neospora 감 염 확진은 조직에서 기생충을 동정하는 것이다[11]. 유산 태아 에서 N. caninum은 주로 뇌, 간, 심장에서 관찰되고[12,13], 이 들 조직에서 병변은 괴사를 동반한 비화농성염의 형태로 나타 나며, 유행병성 유산이 발생한 경우와 임신초,중기에 유산된 태아에서 병변은 더욱 뚜렷하다 $[1,6,7,13]$.

국내에서 N. caninum 감염은 김 등[15]에 의해 처음으로 보고된 이후 소에서 N. caninum 항체 양성률이 증가되는 추 세에 있지만[14], 자연 감염된 양성우로부터 유산된 태아의 병리학적 연구는 활발하게 진행되고 있지 않고 있다. 이에 본 연구는 충남 공주시와 연기군의 목장 4 곳에서 Neospora에 자연 감염된 임신우로부터 유산된 태아에 대해서 병리조직 학적, 전자현미경적으로 관찰을 수행하였던 바 그 결과를 보 고하는 바이다. 


\section{재료 및 방법}

\section{공시 동물 및 시료}

충남 공주시와 연기군의 목장 4곳에서 2008년 3월부터 2010 년 2월까지 2년 동안 Neospora에 자연 감염된 임신우로부터 유산된 태아 7 두와 함께 이들의 혈액과 어미소의 혈액을 채취 하여 실험에 공하였다(Table 1). 유산된 태아에서 혈액은 심장 에서 채취하였으며 여의치 않을 경우에는 흥수를 채취하여 실험에 공하였다.

이들 목장은 부르셀라병과 결핵검사에서 모두 음성이었으며, 예방접종 프로그램에 따라 Infectious Bovine Rhinotracheitis virus, Bovine Viral Diarrhea virus, Myxovirus Parainfluenza3, Bovine Respiratory Syncytial virus, Haemophilus somnus 가 포함된 소 호흡기 5종 종합백신(Bar $\mathrm{Vac}{ }^{\circledR}$ Elite 4-HS, Boehringer Ingelheim, St. Joseph, MI)으로 매년 예방접종해 왔었다.

임신 진단은 직장을 통한 초음파 임신진단기로 인공수정 후 5-7주경에 임신진단한 후, 임신 10-12주경에 재검사하여 확 진하였다.

유산한 경우에는 어미소의 결핵 및 부르셀라 감염 여부를 충남가축위생시험소 공주지소에 의뢰하여 재차 확인하였다.

\section{혈청학적 검사}

Neospora caninum antibody Test Kit (CHEKIT Neospora ELISA, IDEXX Laboratories, Liebefeld-Bern Switzerland)를 사용하여 조사하였다. 모든 혈청 시료는 혈청 희석액으로 10 배 희석하여 항원이 도포된 마이크로플레이트에 $100 \mu \mathrm{l} / \mathrm{well}$ 씩 중복 분주한 후 $37^{\circ} \mathrm{C}$ 에서 1 시간 배양한 다음, 4 회 세척하였 다. 이어서 anti-ruminant-IgG-PO conjugate를 $100 \mu \mathrm{l} /$ well를 분주한 후 $37^{\circ} \mathrm{C}$ 에서 1 시간 배양, 세척과정을 거쳐, $\mathrm{TMB}$ substrate를 $100 \mu \mathrm{l} /$ well씩 분주하여 실온에서 15 분 배양한 후 stop solution을 $100 \mu \mathrm{l} /$ well 첨가하고 $450 \mathrm{~nm}$ 에서 흡광도 $(\mathrm{OD})$ 를 측정하여 아래와 같이 $\mathrm{S} / \mathrm{P}$ 값을 계산하였다.

$\mathrm{S} / \mathrm{P}$ 값 $\%$ )=(sample mean OD-negative control mean $\mathrm{OD}) /$ positive control mean OD-negative control mean OD) $\times$ 100

제조사의 설명서에 따라 S/P값이 $40 \%$ 이상은 양성, $30 \%$ 이상 $40 \%$ 미만은 의양성, $30 \%$ 미만은 음성으로 판정하였다.

\section{병리조직학적 관찰}

Neospora 항체 양성우로부터 유산된 태아를 부검하여 육안 적으로 관찰한 후, 각종 조직을 절취하여 $10 \%$ 중성 포르말린 용액으로 고정하여 통상적인 방법에 따라 paraffin 포매절편 을 만들어 Hematoxylin-Eosin 염색 및 N. caninum의 조직낭포 (tissue cyst)를 관찰하기 위한 Periodic acid Schiff 염색을 실시 하여 광학현미경적으로 관찰하였다.

\section{전자현미경적 관찰}

파라핀 포매한 뇌조직을 탈파라핀한 다음 탈수시켰다. 뇌조 직을 대략 $1 \mathrm{~mm}^{2}$ 로 잘게 세분한후 $1 \%$ osmium tetroxide에 2시간 동안 후고정하였다. 점진적으로 알콜농도를 높이면서 탈수한 후, 조직을 propylene oxide에 침습시킨 후 Epon (Embed 812; Electron Microscopy Sciences, Hatfield, PA)으 로 포매하였다. 조직낭포의 존재를 알기 위해서 조직을 toluidine blue로 염색하여 광학현미경으로 관찰하였다. 조직낭포 가 확인된 조직을 ultramicrotome (Leica EM UC6, Wetzlar, Germany)으로 $70 \mathrm{~nm}$ 두께로 초박절편하였다. 초박절편한 조 직을 grid판에 올린 다음 uranyl acetate와 lead citrate로 이중 염색하여 투과전자현미경[EM1200EX-IItransmission electron microscope (JEOL, Tokyo, Japan)]을 이용하여 $80 \mathrm{kV}$ 에서 관 찰하였다.

Table $1 . \mathrm{S} / \mathrm{P}$ ratio in serum of aborted fetuses and seropositive dams at abortion by ELISA

\begin{tabular}{|c|c|c|c|c|c|}
\hline \multirow{2}{*}{ Herd } & \multirow{2}{*}{$\begin{array}{c}\text { Aborted fetuses } \\
\text { age (days) }\end{array}$} & \multicolumn{2}{|r|}{$\mathrm{S} / \mathrm{P}$ ratio } & \multicolumn{2}{|c|}{ Tachyzoite or tissue cyst presence } \\
\hline & & Aborted fetuses & Seropositive dams at abortion & Brain $^{c}$ & Liver \\
\hline \multirow{3}{*}{ A } & 142 & $<0^{\mathrm{a}}$ & 96.70 & $\mathrm{~L}$ & - \\
\hline & 185 & 78.06 & 100.09 & + & + \\
\hline & 199 & ND & 116.62 & \multicolumn{2}{|c|}{ Mummified } \\
\hline \multirow{2}{*}{ B } & 203 & 93.73 & 95.21 & - & + \\
\hline & 214 & ND & 62.91 & \multicolumn{2}{|c|}{ Mummified } \\
\hline $\mathrm{C}$ & 175 & $<0$ & 122.28 & SL & + \\
\hline $\mathrm{D}$ & 132 & ND & 130.58 & $\mathrm{~L}$ & - \\
\hline
\end{tabular}

ND: Not done.

a: Serosanguinous fluids in the pleural cavity of the aborted fetus.

b: +; Presence, -; Not presence.

': Brain consistency, L; Liquid, SL; Semi-liquid.

A $\mathrm{S} / \mathrm{P}$ ratio; $<30$ was defined as negative, $30 \geqq$ and $<40$ false-positive, $\geqq 40$ positive. 


\section{결 과}

\section{혈청학적 소견}

유산된 태아 7두의 연령은 임신 4-7개월령이였고, 유산된 태아 7 두중 3 두는 혈청학적 검사를 할 수 없었지만, 나머지 4 두중 2 두의 유산 태아는 N. caninum에 대한 양성 반응을 보였 으나, 175 일령의 유산 태아의 심장 혈액과 142일령의 유산 태 아의 혈액이 고인 흉수는 음성이었다. 유산한 어미소는 혈청 학적 검사 결과에서 모두 N. caninum에 양성반응을 보였다 (Table 1). 유산한 경우 어미소의 결핵 및 부르셀라 감염은 음 성으로 재확인되었다.

\section{병리조직학적 소견}

유산된 태아는 육안적으로 전신 부종이 있었고 부검시 복강 과 흥강은 혈액성·장액성 액체로 충만되어 있었다(Fig. 1). 132, 142 일령 유산 태아의 뇌조직은 연화되어 시료를 채취할 수 없었으나, $175,185,203$ 일령 유산 태아의 뇌는 비교적 온전하 였다.

광학현미경적 관찰에서 $175,185,203$ 일령의 유산된 태아 3 두의 간에서 tachyzoite 집락이 관찰되었고(Fig. 2), 이 중 185
일령의 유산 태아 뇌조직에서 크기가 다양한 많은 수의 조직 낭포가 관찰되었다(Figs. 3A, B). 조직낭포는 구형으로 두꺼운 막으로 싸여 있었으며, 신경세포의 세포질내 또는 신경세포 주위에서 관찰되었고 조직낭포 주위로 염증반응은 관찰되지 않았다(Figs. 3C, D). 조직낭포는 많은 수의 bradyzoite를 포함 하고 있었으며 PAS 염색에서 양성반응을 보였다(Fig. 3C). 또 한, 뇌조직에서는 충·출혈 및 국소성 괴사와 함께 광범위한 신경교증이 관찰되었고 국소성 괴사 부위 주위와 혈관주위에 소교세포로 구성된 많은 수의 염증세포 침윤이 관찰되었다 (Figs. 3E-G).

132,142 일령의 유산 태아의 심장, 간, 폐, 신장에서는 주로 괴사를 동반한 약간의 염증세포 침윤이 관찰되었으나, 기생 충은 관찰되지 않았다. $175,185,203$ 일령의 유산된 태아의 심 장, 간, 폐, 신장에서는 충·출혈과 괴사 및 대식세포, 임파구, 단핵구 세포로 구성된 많은 수의 염증세포 침윤이 관찰되었 다(Fig. 4).

\section{전자현미경적 소견}

광학현미경적으로 동정된 조직낭포를 전자현미경적으로 관찰한 바, 조직낭포의 내부에는 길이 2-5 $\mu \mathrm{m}$, 폭 1-2 $\mu \mathrm{m}$ 인
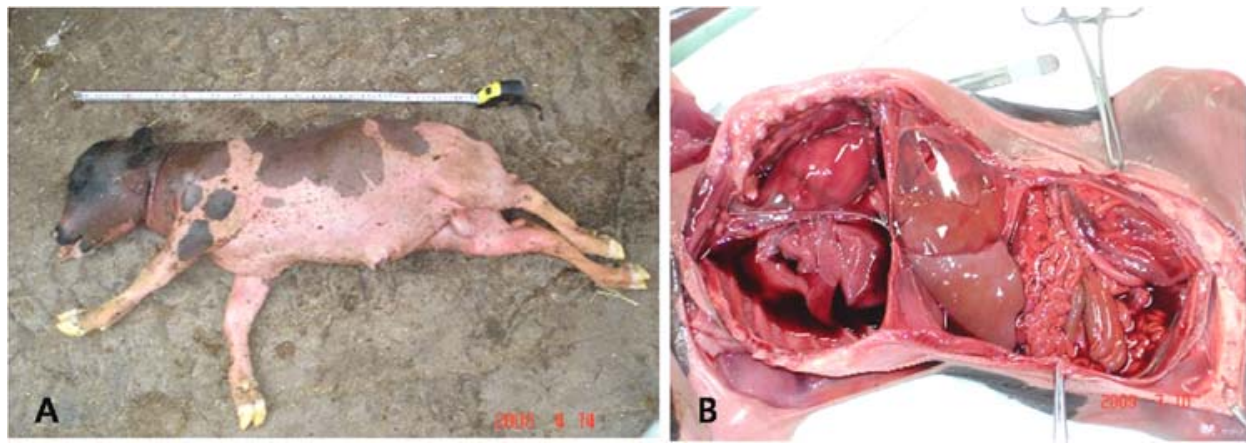

Fig. 1. (A) Marked systemic subcutaneous edema in aborted fetus at 203 days after AI(length of the fetus; C-R: about $70 \mathrm{~cm}$ ). (B) A lot of serosanguinous fluid accumulation in the body cavity of aborted fetus at 185 days after AI. AI: artificial insemination.
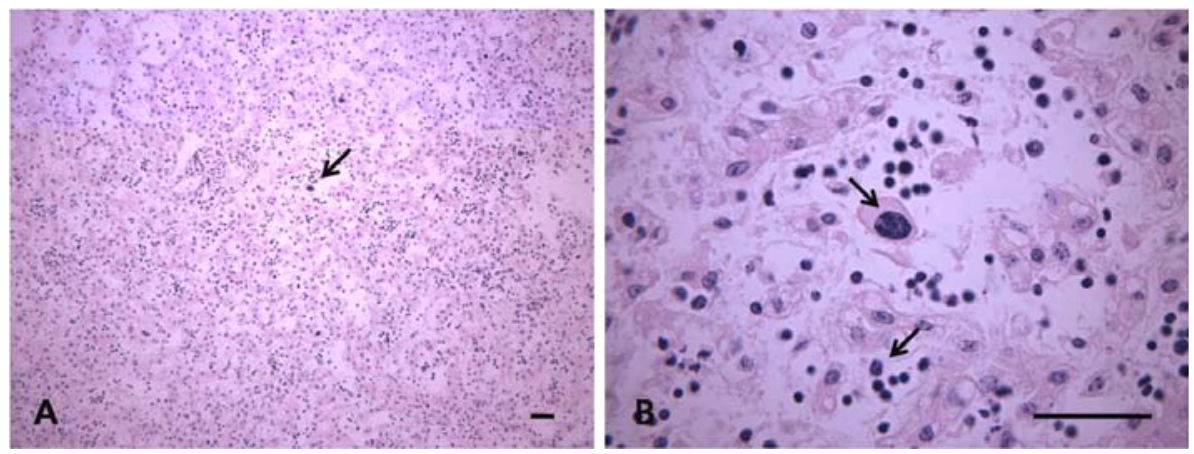

Fig. 2. (A) Diffuse, many lymphocytes and mononuclear cells infiltrations and N. caninum tachyzoites (arrow) in the liver of aborted fetus at 175 days after AI. H-E. (B) Lymphocytes and mononuclear cells infiltrations and N. caninum tachyzoites (arrows). Magnification of (A). H-E. Bar: $40 \mu \mathrm{m}$. 



Fig. 3. A-G. Tissue cysts and encephalitis due to N. caninum infection in the aborted fetuses (A-F: aborted bovine fetus at 185 days after AI, G: aborted bovine fetus at 203 days after AI). Note the absence of inflammation adjacent to N. caninum tissue cyst. (A) Intracellular (arrow) and extracellular (arrow heads) tissue cysts. H-E. (B) Large (arrow) and small (arrow head) tissue cysts. H-E. (C) Tissue cyst. PAS. (D) A thick walled intracellular tissue cyst. Magnification of (A). H-E. (E) Hyperemia, gliosis and perivascular infiltration of mononuclear cells. H-E. (F) Focal central necrosis with scattering of microglial cells at the periphery. H-E. (G) Hyperemia, a central necrotic focus surrounded by infiltration of microglial cells. H-E. Bar: $20 \mu \mathrm{m}$.
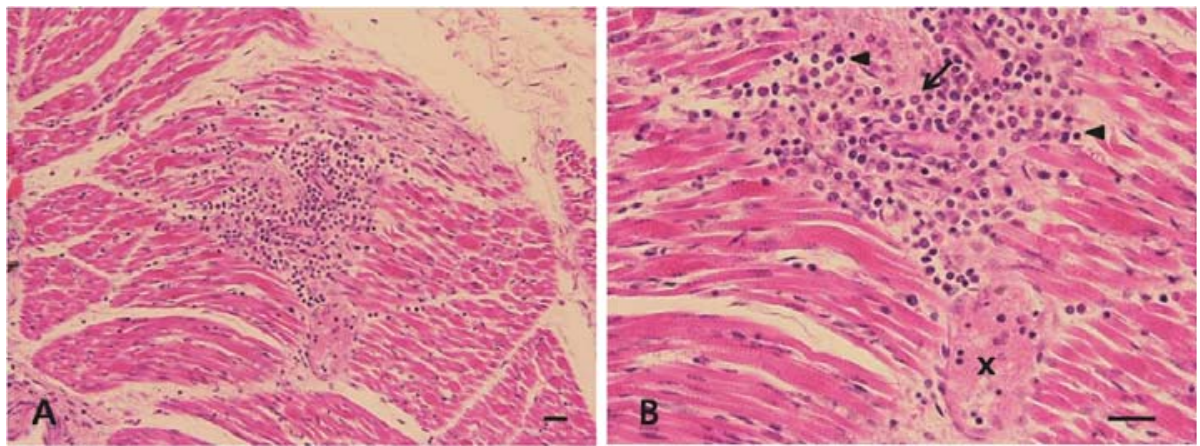

Fig. 4. Myocarditis with necrosis in the heart of aborted bovine fetus at 203 days after AI. (A) Myocarditis with necrosis. H-E. (B) Macrophage (arrow), lymphocytes (arrow heads) infiltrations with necrosis $(x)$ in the heart. Magnification of (A). H-E. Bar: $40 \mu \mathrm{m}$. 



Fig. 5. A-D. Electron-micrograph of the tissue cyst and bradyzoites. (A) A tissue cyst contains approximately 100 bradyzoites. (B) The wall of tissue cyst is irregular in shape and in thickness, measuring approximately $1 \mu \mathrm{m}$. (C and D) Micronemes oriented perpendicularly to the zoite pellicle. The nucleus was located subterminally from the posterior tip. The bradyzoites contain amylopectin granules, electron-thin large-sized (arrows) and electron-dense small-sized granules dense granules (arrow heads) and uniformly electron-dense rhoptries. Abbriviations: $\mathrm{Am}$, amylopectin; $\mathrm{Cw}$, cyst wall; $\mathrm{Mn}$, microneme; $\mathrm{Nu}$, nucleus; Rh, rhoptry.

크기가 다양한 100 여 개의 bradyzoite가 관찰되었다(Fig. 5A). 조직낭포의 막 두께는 대략 $1 \mu \mathrm{m}$ 였고 모양은 불규칙하였다

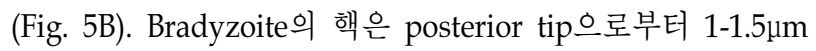
전방에 존재하였고, 세포질 내에는 amylopectin 과립, 전자밀 도가 높고 작은 구형인 과립과 전자밀도가 상대적으로 낮으나 큰 구형의 과립, 전자밀도가 균질한 rhoptry 및 zoite pellicle에 대해 수직방향으로 달리는 microneme이 관찰되었다(Figs. 5C, D).

\section{고 찰}

본 연구에서 132,142 일령의 유산 태아에서는 괴사 병변이 주로 관찰되었고, $175,185,203$ 일령의 유산 태아에서는 기생 충과 함께 괴사를 포함한 뚜렷한 염증성 반응이 관찰되었다. 이는 N. caninum에 의해 유산된 태아에서 나타나는 병변과 조직에서 기생충 발견은 임신 초기나 중기에 유산된 태아에서 뚜렷하다는 보고 $[6,7,13]$ 와 태아의 면역 체계가 충분히 발달하 기 전에 감염시 각종 장기에 심한 염증성 반응이 관찰된다는 보고[1]와 마우스에 실험적으로 Neospora를 감염시켰을 때 태 아에서 나타나는 병변 발현 양상[16]과 일치한다.

175 일령의 유산된 태아의 간에서 다수의 tachyzoite와 뇌조 직에서 충·출혈 및 혈관주위에 소교세포로 구성된 많은 수의
염증세포 침윤을 동반한 광범위한 신경교증을 비롯하여 각종 장기에서 심한 염증성 반응이 관찰되었지만, 태아 심장 혈액 의 혈청학적 검사 시 Neospora에 대한 항체 반응은 음성이었 다. 이는 태아의 체액성 면역 반응이 발현하지 않았거나[11], 자가융해로 인해 태아의 면역글로블린이 분해(degradation) 되어 N. caninum에 대한 특이 항체 수치가 낮아졌기 때문으로 사료된다[24].

본 연구에서 미아라화된 태아를 제외한 5 두의 유산된 태아 에서 관찰된 병변은 N. caninum의 자연 감염 또는 실험적 감염 으로 인해 유산된 태아에서 나타나는 병리조직학적 소견과 일치하였다 $[1,4,6-8,10,12,13,19]$. 하지만, 자연 감염된 유산 태 아에서 기생충이 발견되는 정도는 매우 낮아서 야외 목장에서 유산된 태아 46 두중 기생충 감염의 병리조직학적 소견을 보인 22 두에서 $\mathrm{H}-\mathrm{E}$ 염색 상에서 단지 2두의 심장과 뇌에서 각각 tachyzoite 집락과 조직낭포가 관찰되었을 뿐이다[8]. 본 연구에 서 미이라화되지 않은 유산 태아 5 두중 3 두의 간과 뇌에서 각각 tachyzoite 집락과 조직낭포가 관찰되었으며, 이들 태아 에서 관찰된 병변은 비화농성염의 형태로 뇌, 심장, 간에서 뚜렷하였다. 이러한 소견은 유산된 태아에서 기생충은 주로 뇌, 심장, 간에서 관찰되고 병리조직학적 병변도 이들 조직에 서 비화농성염의 형태로 나타난다는 보고와 일치한다[13].

자연 감염된 목장에서 유산된 태아는 대개 자가융해, 미이 
라화, 침지화되어 광학현미경적으로 조직에서 N. caninum의 tachyzoite나 bradyzoite를 관찰하기 어렵다[7,8]. 본 연구에서 도 뇌조직이 연화되어 시료를 채취할 수 없었던 132, 142일령 의 유산 태아에서 어떤 조직에서도 기생충을 발견할 수 없었 으며, 뇌조직의 상태가 비교적 양호한 3 두의 유산 태아에서 기생충의 집락이 관찰되었다. N. caninum 집락은 광학현미경 적 관찰시 조직낭포의 형태로 관찰되며 이들은 tachyzoite와 bradyzoite로 구성되어 있다. H-E 염색 상에서 광학현미경으 로 집락을 구성하고 있는 기생충이 어느 단계에 속하는지 식 별하는 것은 어렵지만[12], PAS 염색과 조직낭포를 둘러싸는 막의 존재유무에 의해 구별할 수 있다[12,13]. 본 연구에서 발 견된 조직낭포는 PAS 염색에 적색으로 염색되었으며, 이것은 bradyzoite 내 포함된 amylopectin 과립이 PAS 염색에서 양성 반응을 보인 것으로 본 연구에서 관찰된 조직낭포 내 존재하 는 충체가 bradyzoite임을 광학현미경적으로 알 수 있었다. 조직낭포는 내부에 포함되는 bradyzoite의 수에 따라 다양한 크기로 관찰되는데 본 연구에서 관찰된 조직낭포의 크기 또한 다양하였다.

N. caninum과 Toxoplasma gondii (T. gondii)는 형태학적으로 유사하여 광학현미경으로 관찰시 정확하게 구별하는 것이 힘 들기 때문에 전자현미경을 이용하여 형태학적 차이점에 기초 하여 구별하고 있다. 조직낭포의 미세구조를 살펴 보면, $T$. gondii의 경우 막은 매끈하고 두께가 $0.5 \mu \mathrm{m}$ 미만이나 N. cani$n u m$ 조직낭포의 막은 모양이 불규칙하고 0.5-4 쓰로 더 두껍 다[21]. 본 연구에서 유산된 태아의 뇌에서 광학현미경적으로 발견된 조직낭포를 전자현미경적으로 관찰한 바 막의 두께는 대략 $1 \mu \mathrm{m}$ 이고 모양이 불규칙하여 T. gondii와 차이가 있었다. Bradyzoite의 미세구조 또한 차이가 있어 T. gondii와 달리 N. caninum 의 핵은 posterior tip으로부터 대략 $1.5 \mu \mathrm{m}$ 떨어져 존 재하고 핵과 posterior tip 사이의 세포질내에 다양한 과립을 비롯한 몇몇 세포소기관들이 위치한다[21]. 본 연구의 N. caninum에서도 bradyzoite 핵은 posterior tip으로부터 전방으로 1-1.5 $\mu \mathrm{m}$ 떨어져 존재하였고, amylopectin 과립을 비롯한 다 양한 크기의 과립들과 rhoptry, microneme이 핵과 posterior tip 사이의 세포질내에서 관찰되었다. 이상의 소견은 T. gondii 와는 확연히 구별되는 N. caninum의 특징적인 미세구조로 [20,21], 본 연구에서 발생한 유산이 N. caninum에 의한 것임을 확인할 수 있었다.

N. caninum의 조직낭포는 세포배양물에서는 관찰되지 않 으며, 자연 감염된 어미소로부터 유산된 태아의 뇌조직에서 N. caninum 조직낭포가 발견되는 것은 극히 드물다[21]. 본 연구에서는 N. caninum에 자연 감염된 임신우로부터 유산된 태아의 뇌에서 N. caninum 조직낭포를 발견하였고, 조직낭포 내에 존재하는 bradyzoite의 미세구조를 전자현미경적으로 확인하였다.

\section{References}

1. Anderson, M. L., A. G. Andrianarico, and P. A. Conrad. 2000. Neosporosis in cattle. Anim. Reprod. Sci. 60-61, 417-431.

2. Anderson, M. L., C. W. Palmer, M. C. Thurmond, J. P. Picanso, P. C. Blanchard, R. E. Breitmeyer, A. W. Layton, M. McAllister, B. Daft, H. Kinde, D. H. Read, J. P. Dubey, P. A. Conrad, and B. C. Barr. 1995. Evaluation of abortions in cattle attributable to neosporosis in selected dairy herds in California. J. Am. Vet. Med. Assoc. 207, 1206-1210.

3. Barr, B. C., J. D. Rowe, K. W. Sverlow, R. H. Bondurant, A. A. Ardans, M. N. Oliver, and P. A. Conrad. 1994. Experimental reproduction of bovine fetal Neospora infection and death with a bovine Neospora isolate. J. Vet. Diagn. Invest. 6, 207-215.

4. Bartley, P. M., E. Kirvar, S. Wright, C. Swales, I. Esteban-Redondo, D. Buxton, S. W. Maley, A. Schock, A. G. Rae, C. Hamilton, and E. A. Innes. 2004. Maternal and fetal immune responses of cattle inoculated with Neospora caninum at mid-gestation. J. Comp. Pathol. 130, 81-91.

5. Bjerkås, I., S. F. Mohn, and J. Presthus. 1984. Unidentified cyst-forming-sporozoon causing encephalomyelitis and myositis in dogs. Z. Parasitenkd 70, 271-274.

6. Collantes-Fernández, E., I. Arnáiz-Seco, B. M. Burgos, A. Rodriguez-Bertos, G. Aduriz, A. Fernández-Garcia, and L. M. Ortega-Mora. 2006. Comparison of Neospora caninum distribution, parasite loads and lesions between epidemic and endemic bovine abortion cases. Vet. Parasitol. 142, 187-191.

7. Collantes-Fernández, E., A. Rodríguez-Bertos, I. Arnáiz-Seco, B. Moreno, G. Aduriz, and L. M. Ortega-Mora. 2006. Influence of the stage of pregnancy on Neospora caninum distribution, parasite loads and lesions in aborted bovine foetuses. Theriogenol. 65, 629-641.

8. Corbellini, L. G., D. Driemeier, C. F. E. Cruz, L. F. P. Gondim, and V. Wald. 2002. Neosporosis as a cause of abortion in dairy cattle in Rio Grande do Sul, southern Brazil. Vet. Parasitol. 103, 195-202.

9. Conrad, P. A„, B. C. Barr, K. W. Sverlow, M. Anderson, B. Daft, H. Kinde, J. P. Dubey, L. Munson, and A. Ardans. 1993. In vitro isolation and chracterization of a Neospora sp. from aborted bovine foetuses. Prasitol. 106, 239-249.

10. Dubey, J. P. 2003. Neosporosis in cattle. J. Parasitol. 89(Suppl), S42-S46.

11. Dubey, J. P. 2003. Review of Neospora caninum and neosporosis in animals. Korean J. Parasitol. 41, 1-16.

12. Dubey, J. P., D. Buxton, and W. Wouda. 2006. Pathogenesis of bovine neosporosis. J. Comp. Pathol. 134, 267-289.

13. Dubey, J. P., and G. Schares. 2006. Diagnosis of bovine neosporosis. Vet. Parasitol. 141, 1-34.

14. Hwang, E. K. 2010. Seroprevalence of antibodies to Neospora caninum in dairy cattle raised in Kangwan province. Korean J. Vet. Res. 138, 19-24.

15. Kim, D. Y., W. S. Hwang, J. H. Kim, K. Hur, E. K. Hwang, B. C. Lee, Y. H. Jean, J. C. Rhee, and S. H. Choi. 1997. Bovine abortion associated with neospora in Korea. Korean J. Vet. 
Res. 37, 607-612.

16. Long, M. T. and T. V. Baszler. 1996. Fetal loss in BALB/C mice infected with Neospora caninum. J. Parasitol. 82, 608-611.

17. O'Toole, D. and M. Jeffrey. 1987. Congenital sporozoan encephalomyelitis in a calf. Vet. Rec. 121, 563-566.

18. Parish, S. M., L. Maag-Miller, T. E. Besser, J. P. Weidner, T. McElwain, D. P. Knowles, and C. W. Leathers. 1987. Myelitis associated with protozoal infection in newborn calves. J. Am. Vet. Med. Assoc. 191, 1599-1600.

19. Park, B. K., H. S. Kim, S. Y. Ryu, S. W. Cho, and S. W. Kang. 1998. A case report of bovine abortion induced by Neospora sp. in Korea. J. Vet. Sci. CNU. 6, 43-47.

20. Peters, M., E, Lütkefels, A. R. Heckeroth, and G. Schares. 2001. Immunohistochemical and ultrastructural evidence for Neospora caninum tissue cysts in skeletal muscles of natu- rally infected dogs and cattle. Int. J. Parasitol. 31, 1144-1148.

21. Speer, C, A., J. P. Dubey, M. M. McAllister, and J. A. Blixt. 1999. Comparative ultrastructure of tachyzoites, bradyzoites and tissue cysts of Neospora caninum and Toxoplasma gondii. Int. J. Parasitol. 29, 1509-1519.

22. Thilsted, J. P. and J. P. Dubey. 1989. Neosporosis like abortions in a herd of dairy cattle. J. Vet. Diagn. Invest. 1, 205-209.

23. Wouda, W., C. J. Bartels, and A. R. Moen. 1999. Characteristics of Neospora caninum-associated abortion storms in dairy herds in the Netherlands (1995 to 1997). Theriogenol. 52, 233-245.

24. Wouda, W., J. P. Dubey, and M. C. Jenkins. 1997. Serological diagnosis of bovine fetal neosporosis. J. Parasitol. 83, 545547.

\section{초록 : Neospora caninum에 자연 감염된 임신우로부터 유산된 태아의 병리조직학적 관찰}

\section{손정훈 · 조성환*}

(충남대학교 수의과대학)

충남 공주시와 연기군의 목장 4곳에서 Neospora에 자연 감염된 임신우로부터 유산된 태아를 병리조직학적, 전 자현미경적으로 관찰하였다. 유산된 태아는 전신 부종과 함께 부검시 복강과 흥강은 혈액성·장액성 액체로 충만 되어 있었다. 광학현미경적으로 심장과 간에서는 충·출혈 및 심근세포와 간세포의 괴사를 동반한 대식 세포, 임파 구, 단핵구 세포로 구성된 많은 수의 염증세포 침윤이 관찰되었고, 간에서는 간세포의 세포질과 간질 조직에서 tachyzoite 집락이 관찰되었다. 뇌에서는 신경세포내와 주위에서 크기가 다양한 많은 수의 조직낭포가 관찰되었 고, 조직낭포는 구형으로 두꺼운 막으로 싸여 있었으며 내부에는 많은 bradyzoite를 포함하고 있었다. 또한, 뇌조 직에서는 충·출혈 및 국소성 괴사와 함께 광범위한 신경교증이 관찰되었고 국소성 괴사 부위 주위와 혈관주위에 소교세포로 구성된 많은 수의 염증세포 침윤이 관찰되었다. 전자현미경적으로 조직낭포의 막 두께는 대략 $1 \mu \mathrm{m}$

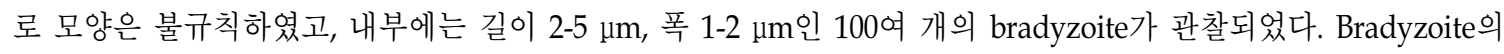
핵은 posterior tip으로부터 1-1.5 $\mu \mathrm{m}$ 전방에 존재하였고, amylopectin 과립, 전자밀도가 높고 작은 구형인 과립과 전자밀도가 상대적으로 낮으나 큰 구형의 과립, 전자밀도가 균질한 rhoptry 및 zoite pellicle에 대해 수직방향으 로 달리는 microneme이 핵과 posterior tip 사이의 세포질 내에서 관찰되었다. 이상의 본 연구는 ELISA검사를 통해 Neospora 항체에 양성반응을 나타내는 임신우로부터 유산된 태아에서 발견된 조직낭포를 전자현미경적으로 관찰하여 N. caninum임을 확인하였다. 